\title{
THE LESSONS LEARNED PROCESS IN THE CZECH ARMED FORCES
}

\author{
Janka KOSECOVÁ \\ University of Defence Brno, Czech Republic \\ janka.kolacnakosecova@unob.cz \\ Monika GRASSEOVÁ-MOTYČKOVÁ \\ University of Defence Brno, Czech Republic \\ monika.motyckova@unob.cz
}

\begin{abstract}
The Lessons Learned Process was introduced in the Czech Armed Forces in 2004. Since then the LL process has become a standard part of the command and control process as well as one of the tools generating input to abilities development of units, formations, and staffs at all levels. The LL process allows to learn from both own and others' mistakes; it also allows to use the best general procedures in all functional areas of development and deployment of armed forces. Not only does the article describe achievements, it also focuses on barriers which impede the efficient development of the system and the LL process. The focus of the article lies in the LL process current state analysis; here the authors come to the conclusion that one of the main problems is that commanders misunderstand the LL process. Another obstacle is the way the identified LL are analysed at the strategic level of command. In the conclusion, recommendations describing the way the identified barriers can be overcome and thus ensure further process optimization are presented.
\end{abstract}

KEYWORDS: stakeholders, knowledge management, lessons learned process, barriers, officer of primary responsibility

\section{Introduction}

One of the basic characteristics of successful managers (and organisations as well) is the ability to learn from both own mistakes as well as from other people's mistakes and knowledge. Every experience, which is used to draw the right conclusion, effect of which can be found in future actions, leads to quality improvement. Knowledge Management $(\mathrm{KM})$, as a systematic process of searching, choosing, organizing, and presenting information in a way which improves workers' comprehension in a specific sphere of interest (Truneček, 2004, p. 12), is based on this general knowledge. Every organisation reaches its maximum efficiency when a set of rules for knowledge sharing, continual learning, innovation, and improvement is used in its management structure - both horizontally as well as vertically. 
Within the Ministry of Defence (MoD), there have recently been several attempts to handle KM and develop its system. As a very significant act can be seen the realization of the defence research project called MENTAL (Buřita, 2008-2011). The final product is available in the intranet environment of the MoD.

In November 2015, individual officers involved in the LL process presented the current state of their units, staffs, and installations at the regular conference organised by the Training Command - Military Academy, Vyškov, Czech Republic. The Training Command Military Academy is an executive coordinator of the LL process in the Czech Armed Forces (ACR). The discussion confirmed the generally known fact that the LL process has been comprehended quite formally although it has been entrenched very firmly in the ACR. This foreshadows a long and difficult way to optimization of the process.

Authors of this article analyses the topic systematically, covering all its complexity and context. She points out possible ways of problem solving. The subject of the question to which she seeks the answer is the possibility of integrating the LL process in a military life and thus becoming a common part of it.

\section{The Lessons Learned Process} within the Ministry of Defence

The general purpose of the LL process (from knowledge management point of view) is to keep the knowledge of an organisation, i.e. turn individual experience into lessons learned so that it could be analysed, generalized, and used for further ability development of armed forces. The specific goal of the LL process in the ACR is to make sure that the lessons learned and suggested measures reach those command and control levels having responsibility for particular spheres.
The LL process has its own particularity at different combat branches. Activities of the Land Forces of the ACR, which is the biggest and the most structured part of the ACR, represent the core of the LL process.

At the Air Force, attention is paid to professional air accidents investigation procedures and causes leading to air accidents. The aim of both processes is not to repeat the same mistakes again. What can be seen at the Air Force is that fulfilling tasks coming from the LL process has been partially omitted. Every cause of a plane crash is periodically generalised by the Air Force once a month. For many years after each flight action there has been given debriefing to all executive pilots. The process of professional air crash investigation is integrated in inner directives. These directives exactly delimitate powers of service authorities and determine principles of unified investigation procedures. A significant executive role is played by the Air Accidents Investigation Committee. (Sekce dozoru a kontroly MO, 2004). All suggested security measures are put into practice after being approved by either an authorised commander or any other commissioned worker. Designated air forces personnel regularly take part in conferences on flight safety. These conferences are organized by the Air Accidents Investigation Institute (ÚZPLN, 2016).

Very high efficiency of the LL Process can be seen at Special Forces. Due to the support coming from the commanding officers, the right motivation and understanding the significance of using gained knowledge, the process has been introduced into everyday practice. Their knowledge and lessons learned, however, come from a very specific environment; that is why not all of them are suitable for wider generalisation.

The system of LL process management is entrenched in the military regulation marked as "Vševojsk-1-1" 
(2009) and additional regulation marked as Vševojsk-51-12 (2010). These regulations set tasks for authorised officials of formations and units. Military doctrine (2015) dealing with the LL process states that "the supreme body being responsible for development and implementation of the
LL process in the Czech Armed Forces is the Chief of the General Staff of Armed Forces of the Czech Republic (CGS)" who carries out these activities via his subordinate parts of the General Staff, as can be seen in Figure no. 1.

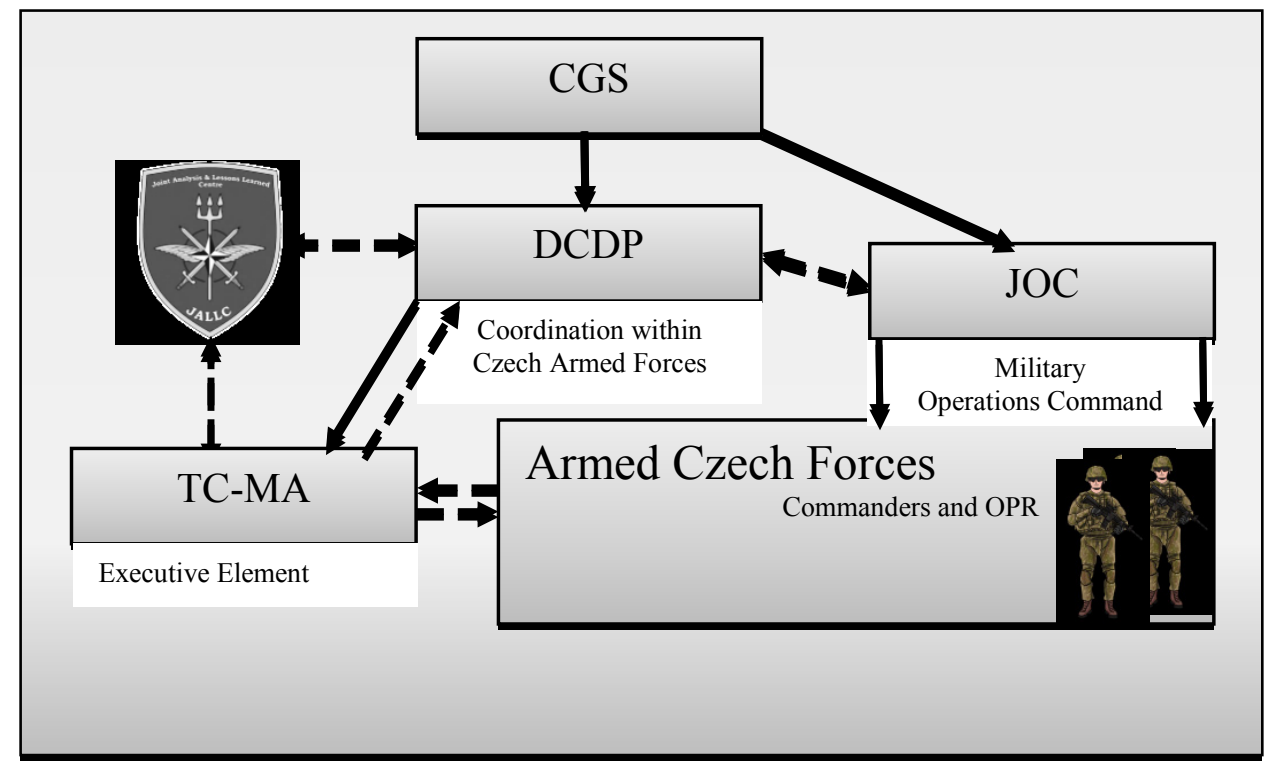

Figure no. 1 Management structure of the LL Process in the Czech Armed Forces

Division of Capabilities Development and Planning (DCDP, MoD) functions as a conceptual and coordinating element in the LL process. The Division director specifies the focus of the LL process and its incorporating into main documents of the ACR. The division works as a professional guarantor that is responsible for the structure and contents of the all-department Database of Lessons Learned (DbLL). This database is maintained by the Doctrine Centre, Training Command - Military Academy, Vyškov. Every year, the centre gives the Chief of Staff a report on current state and results of the LL process.

The Joint Operations Centre JOC (MoD) is responsible for controlling the forces and resources earmarked for preparation and conducting military operations. It also distributes the Lessons Learned via the Division of Capabilities Development and Planning DCDP (MoD).
The Division suggests, accepts, and implements corrective measures which help introduce new Lessons Learned and do away with imperfections revealed during the LL process implementation.

Centre of Doctrine (CDo) is a part of the Training Command - Military Academy (TC-MA). The main mission of the workplace is to be an executive body to support the LL process in the Czech Armed Forces. The CDo focuses on the LL process theory development and on training people who are responsible for the LL process at individual organization units. It also provides these people with methodical help. The CDo cooperates with the Allies and with the Joint Analysis Lessons Learned Centre - JALLC. The CDo is an executive element, or, to put it differently, an administrator of the all-department DbLL.

Commanders of different combat branches provide (within their field of 
competence) conditions for the job of OPR (Officers of Primary Responsibility), who accomplish tasks within the LL process. The commanders also provide training for the OPR. They suggest, accept, and implement corrective measures which help introduce new Lessons Learned and do away with imperfections revealed during the LL process implementation. Their main task of OPRs is to collect Lessons Learned at their units, evaluate new information, and suggest further procedure in dealing with the new information to their commanders.

Units of organisation of the MoD (Státní tajemník MO, 2015), which are subordinate to the Chief of the General Staff (CGS), suggest, accept, and implement corrective measures which help introduce new knowledge and do away with imperfections revealed during the LL process implementation.

Other units of organisation of the MoD (Státní tajemník MO, 2015), which are not subordinate to the Chief of the General Staff, deal with measures coming from the LL process within their sphere of competence following the input of the head of the department. They have no particular duty within the LL Process but they accomplish tasks required by the CGS.

The Minister of Defence takes decisions on implementing individual measures coming from the LL process; his decision is based on suggestions and requirements of the CGS and other direct subordinates of the MoD.

The JALLC is NATO's centre for performing Joint Analysis of operations, training, exercises and experiments, based on joint analysis requirements generated by both NATO strategic commands. It provides information support of bodies with the NATO command structure as well as the Allies. The JALLC issues various manuals, organises workshops, manages the LL database and provides its distribution and sharing within the NATO command structure. It also maintains the NATO Lessons Learned Portal.

Individual elements of the LL system in the $\mathrm{MoD}$, as seen in Figure no 1 , play different roles on the LL process. Based on the stakeholder's analysis results, it is possible to depict their place and significance in the LL process, as can be seen in Figure no. 2.

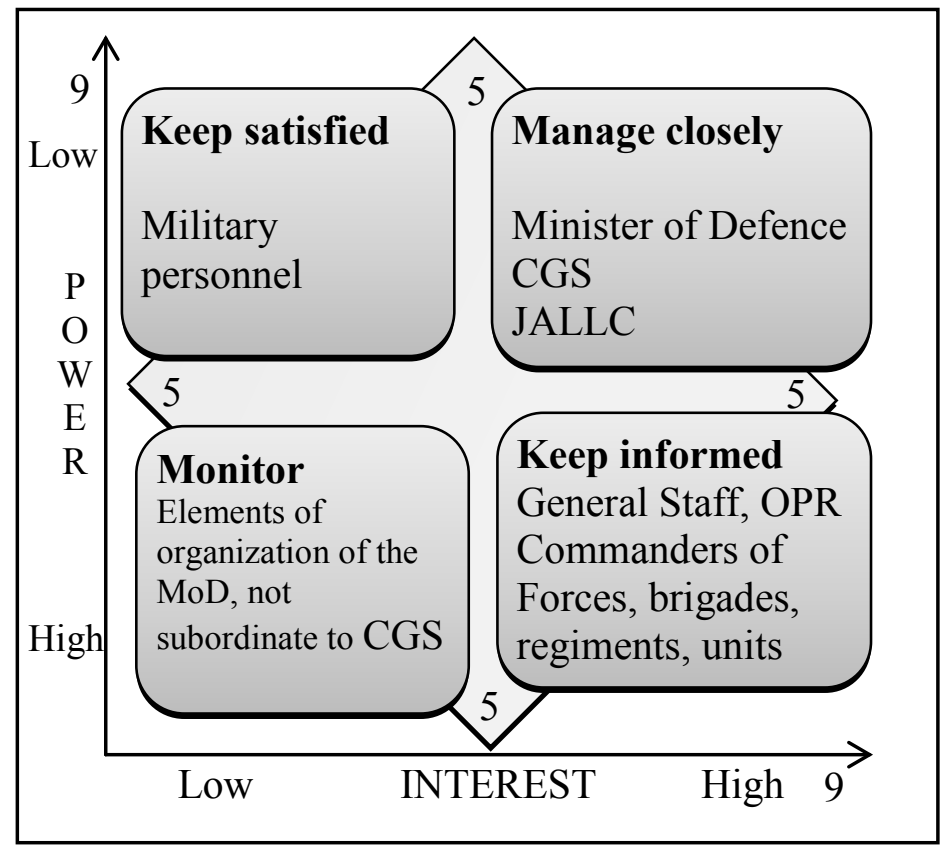

Figure no. 2 Stakeholders analysis 


\section{The LL Process Analysis Conclusions}

Since its introduction in 2004, the LL process has become an accepted part of both the training and operational practice in the ACR. A crucial moment of implementing the LL process was the effort of CGS of that time who pressed establishing of a system which has gradually developed into current form.

The main momentum of the process is purposeful and permanent effort of the CDo, which carries out the executive function. Cooperation $\mathrm{CDo}$ and DCDPMoD, which coordinates the process on operational and strategic levels, is significant and very positive.

Within the LL process, the greatest attention is paid to getting and processing LL in the field of command and control during training and real operations, both of which at tactical levels. Exercise analysis and contingency generalization at all ACR training activities have been traditionally processed and evaluated. Due to the effort of CDo and TC-MA, Vyškov, working network of trained OPR has been created. In 2007-2015, 194 people have passed the basic course. Currently, 65 of these people work in a structure which covers virtually all spheres and levels of ACR activities.

The monitored period of time showed that $70 \%$ of trained specialists do not work within their field of specialisation. However, changes caused especially by organizational and personnel shifts can be perceived in a positive way. Trained OPR are very often promoted; then, by virtue of their new authorities and responsibilities they have in their new positions, they are able to manage the LL process competently.

Since 2010, there have been 548 results recorded and filed in the LL database managed by CDo. There are 439 "Observations" which have only passive information value from the practical use point of view. There are 90 "Lessons Identified". The most precious category includes "Lessons Learned" (there are only 19 in 6 years) which were taken into consideration by units and command and control authorities at different levels.

The only workplace which fully deals with the LL process support in the ACR is CDoTC-MA, Vyškov. Practice proved that including the process in CDo's organisation structure has been very useful because new knowledge and LL can be directly incorporated into doctrinal publications (even into documents of legal character) being processed and prepared by the CDo.

The Centre of Doctrine organizes workshops and conferences on the topic of LL process, which help evaluate the LL process. They also set further trends and mutual sharing of LL. The Centre also provides education in the form of courses, and instructor/mentor activities.

\section{Imperfections in the LL Process and} their Causes

The above mentioned statistics indicates that the LL process, in spite of provable results, has not become an inseparable part of the ACR management. This was also proved by the results of a questionnaire survey which was carried out from January to May, 2016. There were 47 respondents (ranking from Major to Lieutenant Colonel) who, at the time of the survey, were taking an officer's course at the University of Defence. The survey proved that there still are flaws in the LL process which had already been identified in the LL process analysis (Pilař, Bartek, Beneš, \& Varga, 2012) and in "Report on LL process in the ACR" (2015).

The main imperfections are:

- there is still no support from the commanders who do not endorse the use and development of the LL process - the process is still a marginal matter;

- frequent organizational changes, including personnel changes in the ACR, which negatively influence the use of the LL process; 
- low promotion of the LL process (lessons at schools, professional courses, commanders' meetings, etc.);

- trained OPR do not have enough time for their jobs because the position of an OPR is beyond the scope of their basic duties;

- there are no service posts of OPR in the ACR.

A detailed analysis and the questionnaire survey results specify an array of barriers which can be divided into two possible areas:

- work style of commanders and managers;

- strategic control efficiency.

\section{Managers}

Workstyle of Commanders and

Taking measures is not enough to do away with the above mentioned problems.

Deformed management culture of the MoD. This especially refers to nonfunctioning proceedings - though, to support the proceedings, a procedural model has been being created (using the ARIS tool) for more than 10 years. The (2010) audit report says that: "The organization management is not systematically building a culture of systematic improvement. In this context, the procedural model can be applied via the approach coming from below by meeting the needs of end users rather than by promotion coming from above - from the management".

There is an overwhelming feeling that "...to admit there is an imperfection means to admit my failure". This way of thinking, which still can be seen in a lot of commanders and managers, comes from the past and still is quite enrooted in the ACR.

Not understanding the meaning of the LL Process. Although the LL Process is logical and, in some measure, every single person applies it in his/her everyday life, a lot of commanders and managers do not understand it in the whole context or they do not know the structure and significance of all included elements in the LL system. Sometimes, processing the data for the database is seen as unnecessary bureaucratic burden. A huge barrier is the inability to carry out analytical activities at a given level. Thus, the "Observation" cannot be incorporated into the "Lesson Identified" and, consequently, into the "Lesson Learned".

Insufficient level of education in the field of LL. Every functional and efficient process in every organization is based on people. Without qualified personnel it is not possible to enhance the efficiency of the LL process. Commanders and managers in all structures of Armed Forces, OPR collecting and sharing lessons learned, analytical workers - these are individual categories of personnel which play a specific part in the overall process. There is a basic OPR course under way; however, no decision has been taken concerning their further education, purpose of which would be to deepen the acquired knowledge and skills. Educating commanders and managers is still a challenge which needs to be dealt with systematically. A significant form of educating military personnel is represented by professional, in particular career courses, organized by the TC-MA, Vyškov, and the University of Defence, Brno. As very positive can be seen the fact, that the issues of LL have gradually been included in the curriculums of these courses.

\section{Strategic Control Efficiency}

Procedural model is set up inconveniently. Within the $\mathrm{MoD}$, the field of LL is included in the group of processes called "Preparation and training of armed forces" as a supportive process. This is in sharp contradiction with the complex conception of armed forces development following the DOTMPFLI methodology (Doctrines, Organization, Training, Material, Personnel, Facilities, Leadership, 
and Interoperability) as well as with, so called, doctrinal cycle.The field of LL should be a part of the main process of abilities development, which is not currently included in the Procedural model of the MoD at all. There is little use of the procedural model and the ARIS tool.

Little interconnection between tactical and strategic levels of control within the LL process. An array of LL ends up in a database; possibly they are included in a publication being processed by the TC-MA, Vyškov. Taking essential measures in the field of activities of individual MoD divisions, possibly at the level of the CGS or the Minister of Defence, happens very sporadically.

Absence of a workplace on a strategic level, main task of which would be dealing with $\mathbf{L} \mathbf{L}$ process. Althoughthe DCDP, MoD works as a coordinator of the LL process on a strategic level, the capacity of a worker, who deals with the issues of the LL process, is limited due to further duties this person has to fulfil. If the structure of the DCDP, MoD (possibly JOC, MoD) included an element, which would fully deal with operational and strategic analyses, and, at the same time, with strategic control of the LL process, the efficiency of the process would significantly increase. Undoubtedly, transfer of LL from a tactical level to operational and strategic levels of armed forces management would improve, too.

\section{Recommendations for the \\ LL Process Optimization}

Current state of the LL process in the ACR is a good starting point for its further development despite of all the barriers mentioned above. The next paragraphs describe measures, which, if put into practice, will help rationalize and increase efficiency of further development of the ACR:

- Provide stabilization of trained personnel. It can be assumed that introducing new rules for career systemization following the principles of amended Act no. 221/1999 Coll., on regular soldiers, will improve the career order and predictability of personnel training, too. Thus, it will be possible to eliminate cases when appointed and trained OPR are transferred to other positions shortly after they finished the OPR course.

- Create conditions for OPR activities. It means to create some time space for OPR at troops, units, and staffs of the ACR. This can be achieved by selecting suitable people who will devote their time to collecting and processing Lessons Learned beyond the scope of their duties, or by creating new service posts for OPR at brigade staffs, at JOC MoD, and DCDPMoD.

- Improve the $L L$ process training programmes for the officers of the ACR. Since 2015, education in the field of Lessons Learned Process has been included in study programmes of all career courses. It is necessary to carry on with further educating of already trained personnel in the field of analyses, e.g. in the form of a follow-up courses.

-Correction of the procedural model at the MoD. Since information, experience, and knowledge are of a complex character, it is not possible to consider it from a training point of view; in the process model of the MoD, it will be necessary to incorporate the field of LL as a sub-process of the main one called "Capabilities Development of Armed Forces". It will also be necessary to establish a position of a gestor who will be responsible for data updating for this process.

\section{Conclusion}

Implementing the LL process within the MoD is built on a strong foundation. Because it is based on people throughout the whole structure of the armed forces as well as in strategic control bodies, development of the LL process, as a tool of command and control, will take many years 
and will depend on creating a healthy organizational structure. As in other fields, this process will function only when people understand its importance and tangible results will be seen. Otherwise, professional soldiers will perceive this process as an unnecessary administrative burden. Nevertheless, without the support of the top representatives of the MoD and commanders at all levels, the process cannot be successfully implemented; it would be further used in a formal way. The CDoTC-MA, Vyškov workplace, which must be filled with experienced workers, must stay the main driving force of the process.

\section{REFERENCES}

Buřita, L. (2008-2011). Projekt obranného výzkumu.: MENTAL - Management znalostí $N E C A \check{C} R$. (1 ed.). Brno: Univerzita obrany.

IDS Scheer (ed.). (2010). ARIS audit pro Ministerstvo obrany: Odkryje potenciál platformy ARIS v podmínkách vaši organizace. 1. Brno: IDS Advisory s.r.o.

Náčelník Generálního štábu AČR (Ed.). (2015). Zpráva o stavu v oblasti získávání poznatků a využivání zkušeností v AČR za rok 2014. Praha.

Pilař, R., Bartek, H., Beneš, J. \& Varga, P. (2012). Analýza procesu získávání poznatků a zkušeností v AČR 2012. Vyškov.

Pub-54-01-01. (2015). Ziskáváni poznatků a využiváni zkušeností v Armádě České republiky: Vojenská doktrina. 1. Vyškov.

Sekce dozoru a kontroly MO. (2004). Rozkaz Ministra obrany 9: Odborné zjištování př́čin leteckých nehod vojenských letadel. Praha: Ministerstvo obrany.

Státní tajemník MO. (2015). Rozkaz Ministra obrany 92: Organizační řád Ministerstva obrany. Praha: Ministerstvo obrany.

Truneček, J. (2004). Znalostní podnik ve znalostní společnosti (2. vyd. ed.). Praha: Professional Publishing.

ÚZPLN: ÚSTAV PRO ODBORNÉ ZJIŠŤOVÁNÍ P̌̌ÍČIN LETECKÝCH NEHOD. (2016), available at: http://www.uzpln.cz/cs/o-nas

Vševojsk-1-1. (2009). Povinnosti funkcionářu útvarů a jednotek pozemního vojska: 4. Doplněk. Praha.

Vševojsk-51-12. (2010). Zásady a způsob organizace ziskávání poznatků a využivání zkušeností v Armádě České republiky. Praha: Ministerstvo obrany. 